\title{
ISLAM, CORRUPTION, GOOD GOVERNANCE, AND CIVIL SOCIETY: THE INDONESIAN EXPERIENCE
}

\author{
Azyumardi Azra*
}

\begin{abstract}
Corruption is no doubt one of the most serious problems faced by many countries, including Muslim countries such as Indonesia. Sometimes it might seem that the teachings of Islam - a religion which prohibits corruption - alone do not work to prevent Muslims from conducting such harmful acts. The author of this article therefore looks at other factors that influence Muslims in their daily lives and reviews the status of governance. In his view, one way to address the problem of corruption would be the fostering of good governance. However, at the same time Muslims would need a vibrant and dynamic civil society that can play a crucial role in the creation and empowerment of good governance. In Indonesia, a majority Muslim country - in fact the largest Muslim country in the world - a large number of Islam-based civil societies exist. The author discusses the role of Islamic teachings against corruption, and the recent experiences of Indonesia in combating this vice, particularly the role of an Islamic civil society sphere.
\end{abstract}

\section{The Teachings of Islam against Corruption}

One of the ways to address the problem of corruption in Muslim societies is through the creation of good governance. However, at the same time a vibrant and dynamic civil society could play a crucial role in the creation and empowerment of good governance. Indonesia is blessed with the existence of a good number of Islam-based organisations.

Religion - Islam in particular - clearly opposes any form of corruption. The ethical teachings of Islam obviously do support the efforts to eradicate corruption as well as to create good governance. Islam puts very strong emphasis on morality and ethics (al-akhāq al-karimah) both at the levels of personal as well as communal life. In fact, according to Islam, the Prophet Muhammad was sent in order for human beings to achieve noble morality and ethics. In a well-known hadith he is reported to have said: "I was only sent for perfecting morality" (innamā bu ithtu li-utammima

* Azyumardi Azra is Professor of History and Director of the Graduate School at Syarif Hidayatullah State Islamic University, Jakarta, Indonesia. 
makārim al-akhlāq). ${ }^{1}$ Therefore, Islam is opposed to any kind of transgression of noble ethics, such as corruption and other injustices. Islam unequivocally prohibits bribery, stealing, and robbery. Islam also forbids Muslims to steal private and public funds and wealth. Moreover, Islam empathically prohibits corruption which is considered as illicit or illegal activities for private or group material gain, and/ or as abuse of trust, power, and public office/position in the interest of private or group gain.

Islam teaches that power and public positions held by leaders are an amānah (trusteeship) endowed by God to human beings. Holders of public offices are accountable to both God and the community. As khalifah, representatives of God on earth, they are also responsible for the enforcement of justice ( 'adālah), not only towards the people but also towards themselves. Otherwise they will be responsible for corruption (fas $\bar{a} d)$.

Islam prohibits Muslims to practise any excessive attitude and act (isrāf) in any aspect of life. Therefore, Islam is against the excessive accumulation of wealth by way of unlawful or illegal means, such as corruption. The accumulation of wealth is allowed only through halāl (lawful) and tayyib (good) means. A certain amount of the halāl wealth should be donated to the poor and the weak and other disadvantaged people as almsgiving (zakāh, infāq, șadaqah).

Islam is also opposed to 'greed'. Those Muslims who fail to control their greed - especially to material things - are regarded as having downgraded their own humanity even to the level of animals. Therefore, Muslims are obliged to conduct severe efforts $(j i h \bar{a} d)$ against their greed. This is in fact the 'greater jihād' as opposed to the 'lesser jihād', that is the waging of war in defence of Islam. Islam urges Muslims to live in a modest and middle way (wasat). Islam also encourages Muslims to feel satisfaction ( $q a n \bar{a}{ }^{\prime} a h$ ) with what they have gained through halāl, permissible or lawful, means. These teachings are in fact part and parcel of Islamic spirituality (Sufism) that is commonly practised by independent Muslim mystics as well as those who are affiliated with a tarīqah or Sufi brotherhood.

Furthermore, Islam urges the leaders to be 'good exemplars' (uswah hasanah) for all people; giving real example, not simply by talking. The religion also appeals to the believers to continually give reminders to others (tawsiyyah) to refrain themselves from any wrongdoing in a wise way (bi-'l-hikmah), good example (maw'izah hasanah), and civilised discussion (mujādalah). Moreover, if necessary, Islam exhorts Muslims to enforce Islamic prohibitions of corruption in a vigorous manner based on the principle of al-amr bi-'l-ma 'rüf wa-'l-nahy 'an al-munkar, enjoining good and forbidding evil

Similarly, local cultures in Indonesia in general regard corruption as a shameful act that must be avoided. Various cultural systems and groups emphasise that people should live in a modest way, not being misled by uncontrollable lust and 
greed. However, with the penetration and intrusion of materialistic and hedonistic lifestyles, these local cultural values have eroded significantly. More and more people think and act in pragmatic ways to accumulate wealth by abusing their power and public positions.

\section{What is Corruption?}

Before proceeding too fast towards the remedies for the evil of corruption, it is necessary to define the kind of 'corruption' that is currently referred to in Indonesia as KKN (korupsi, kolusi, nepotisme, i.e. corruption, collusion, and nepotism).

Conventionally, the term 'corruption' refers to any illicit and illegal activities for personal or collective gains. In more recent discussion, there is a general emphasis that 'corruption' is "the use and abuse of power or public position for individual and collective gains". Based on this definition, Philip ${ }^{2}$ identifies three general definitions that are mostly used in various discussions on corruption:

- Corruption that is centred in public office (public office-centred corruption), which is defined as the "acts and policies of particular public official that is not in accord with his/her official position in order to get personal gains, or gains for certain people who have close relationship with him/her such as family, relatives, and friends". This definition, as one might observe, includes corruption and nepotism, i.e. establishing patronage based on familial relationship (ascriptive) rather than on merit.

- There is the definition of corruption that centres on the effect of corruption on public interest (public interest-centred). In this respect, corruption can be said to have taken place when a power holder or public official conducted certain acts and policies on the basis of the will of other individuals who have provided money or other kinds of material 'rewards'. In line with this definition, corruption can be said to have taken place when a holder of public office conducted certain acts or policies in favour of certain people who have given him/her material rewards that in turn corrupted his/her official position and public interests.

- Finally, we come across a definition of corruption that centres on the market (market-centred). This definition is based on analyses of corruption that employ various theories of social and public choices as well as of economic approaches within the framework of political analysis. In this respect, corruption is an 'extra-legal' institution that is used by individuals of groups of people in order to influence policies and practices of bureaucracy. Therefore, this kind of corruption indicates that individuals and groups of people who 
are involved in the process of decision making are more prone to corruption than any other individuals or groups.

Within this framework still, corruption also means the abuse of power by public servants, government or public officials in order to gain extra income from public resources. Thus, public position or office is used (or abused) as business venture that should be exploited to get the maximum possible gains.

Based on the three groups of definitions above, a number of academic forums, international organisations - such as the Asian Development Bank (ADB), the World Bank, Transparency International and others - and also government officials that have been allegedly involved in corruption, propose a minimalist definition that would include almost all forms of corruption. This 'minimalist' definition was in the end formulated by Leiken, ${ }^{3}$ according to whom "corruption is the use and abuse of public power for personal material gains as well as political benefits".

Elaborating that kind of 'minimalist' definition, the World Bank gives a detailed elaboration of acts that are included in corruption:

Public office is abused for private gain when an official accepts, solicits, or extorts a bribe. It is also abused when private agents actively offer bribes to circumvent public policies and processes for competitive advantage and profit. Public office can also be abused for personal benefit even if no bribery occurs, through patronage and nepotism, the theft of state assets, or the diversion of state revenues. ${ }^{4}$

A similar minimalist definition is also put forward by Syed Hussein Alatas. ${ }^{5}$ In his opinion, "corruption is the abuse of trust in the interest of private gain". Based on this minimalist definition, Alatas proposes typologies of corruption:

- 'transactive corruption', that is corruption that takes place on some kind of agreement between a donor and recipient for mutual gains;

- 'extortive corruption', that is corruption which involves extortion to avoid possible legal consequences for those who are involved and close to the actor of corruption;

- 'investive corruption', that is corruption which begins with promises - a kind of investment - to anticipate certain gains in the future;

- 'nepotist corruption', that is corruption which takes place because of certain favourable treatment in job promotion in public office and in projects for close relatives;

- 'autogenic corruption', that is corruption which takes place when a public official gains certain benefits for his/her knowledge as insider (insider's information) on public policies that he/she must otherwise keep secret; 
- 'supportive corruption', that is protection or even support certain acts of corruption which takes place within power struggle.

Thus, from the minimalist definition, corruption in the end can be divided into a number of typologies and categories. Furthermore, corruption can also be categorised based on its place; in public sector and private; or based on its intensity, isolative or systematic; national or local, personal or institutional, traditional or modern kind of corruption.

\section{Combating Corruption}

All of these categories, typologies and the kinds of corruption would be very helpful not only for a better knowledge of corruption, its causes and consequences, but also for finding the ways to solve it. They would help to formulate strategies to combat corruption; to develop political will against it as well as to mobilise an anti-corruption movement within the public in general.

Corruption then can be eliminated by recognising various categories, typologies and kinds of corruption in certain contexts. Briefly, the anti-corruption movement includes two-stage processes: first, the stage of policy formulation to address the main root-causes of corruption; and, second, the stage of creating and enhancing political will which is crucial for the implementation of anti-corruption programmes.

The two-stage processes reflect the crucial role of government and bureaucracy in the war against corruption. This is, of course, only one of the first steps towards the creation of a democratic, credible, accountable government in the management of the public sector. Therefore, the first crucial step in the eradication of corruption is to accelerate the demands and pressures for reforms at the level of government, then at the level of business sector, and finally at the level of the public in general.

One of the most important determining factors in the success of anti-corruption efforts is the political will at the highest level of government. Having conducted a number of studies on corruption, Morgan points out that one conclusion which often emerges is that a sincere commitment by high level leadership to counter-corruption efforts is a crucial component of successful campaigns. ${ }^{6}$

Therefore, the failure of anti-corruption programmes in many countries is not to be blamed on 'incomplete' or 'insufficient' laws and regulations or lack of anticorruption bodies, but more on the absence or lack of commitment, seriousness, and sincerity on the part of the highest government officials. In most cases, they rarely even talk about corruption eradication.

As a result, there is a strong impression that if they do talk about corruption then it is only for political publicity or for additional legitimacy. In fact, there is a strong tendency among them to apply political cost-benefit analysis in deciding whether 
or not to implement anti-corruption policies and programmes. Therefore, it is the duty of anti-corruption agencies and the public in general to continually pressure them to ensure that they have the political will to carry out the necessary corruption eradication policies and programmes.

Basically, there are four kinds of policies that can be taken by government policy makers in order to effectively minimise - if not wholly eradicate - various kinds of corruption:

- reforming policies that in one way or another could be abused by public officials;

- reforming the structure of salary and other material incentives that apply in bureaucracy and other public institutions;

- reforming law enforcement agencies and expanding their capacity to enforce law and order;

- lastly, strengthening the rule of law.

There is little doubt that the success of corruption eradication depends on the ability to carry out the four reforms in a simultaneous, comprehensive and consistent way.

In the next stage, the four kinds of reforms mentioned above can be integrated with the recommendations that have been issued by the World Bank ${ }^{7}$ on the strategies to eradicate corruption. There are several main components that should be included in any strategy to comprehensively eradicate corruption:

- Developing a bureaucracy that is based on the rule of law with a salary structure that honours employees for their honesty. There should be an empowerment of a merit system in the process of recruitment and job promotion, so that it will be able to prevent the political interference in both. There should also be an empowerment of financial control in order to prevent misuse of public funding in an arbitrary manner.

- Preventing employees from conducting corrupt acts by limiting their authority in the formulation of policies as well as in the management of funding.

- Enhancing the accountability of government employees by strengthening monitoring; anti-corruption agencies and the public in general should also enhance their control and monitoring.

The empowerment of control and monitoring functions of such institutions also needs strategies; so that the eradication of corruption can be conducted comprehensively. There are at least three strategies in this respect: 
- Strengthening the official institutional and mechanism control in order to supervise and monitor employees, officials, and other holders of public office.

- Enhancing public pressures for these institutions to function in a more effective way; this can be done through free press, decentralisation of administration, and greater transparency on the part of government in decision-making processes.

- Educating the public to put moral and political pressures for the eradication of corruption. The public should also be taught on such concepts as 'public office', 'public service' as well as on the social, economic, political and religious consequences of corruption for public life.

\section{The Creation of Good Governance}

Corruption, no doubt, is still one of the most serious and acute problems Indonesia faces today and, of course, one of the biggest constraints in the efforts to create good governance. In spite of this, in the last several years the efforts to combat corruption have continued to gain momentum. However, there is not much convincing evidence that this rampant and acute problem could be solved in the near future. Despite accelerated efforts to bring corrupt individuals to justice, Indonesia remains one of the most corrupt nations of the world.

The fight against such a scenario is clearly not easy. The difficulties are even becoming more complicated, for corruption seems to have become a 'culture' at every level of Indonesian society, having even stronger roots in public and societal lives. Serious and concerted efforts must be conducted, however, so that corruption can be reduced, if not eliminated altogether. Therefore, we would also like to suggest a number of steps that can be taken in the fight against corruption, a fight that is so instrumental when embarking on the creation of good governance.

The eradication of KKN and - by the same token - the creation of good governance has been a central issue in Indonesian public debate since the fall of President Soeharto in 1998. There have been increasing demands from many sectors of Indonesian society that the government should establish a special programme for combating KKN. One of the results towards that end is the formation of the Anti-Corruption Commission (Komisi Pemberantasan Korupsi/KPK). Despite some scepticism among the wider public over whether or not the KPK will eventually be able to combat corruption effectively, it is also clear that the KPK has recently become an increasingly powerful means to investigate cases of corruption among high-ranking public officials and to bring them ultimately to justice.

On the other hand, civil society organisations have also been trying to play a greater role towards that end, by forming, for instance, a number of 'watchdog bodies' - among them the powerful Indonesian Corruption Watch (ICW) - in 
an attempt to monitor the working of government institutions and other public offices. Since then several policies and programmes have been implemented by the government. However, one has to admit that so far not much progress has been achieved. ${ }^{8}$ There are several inhibiting factors that seem to make the efforts to create good governance in Indonesia a very difficult task.

One of the biggest hurdles towards the creation of good governance is the fact that Indonesia, as far as the political culture is concerned, has long been a 'soft state' in the Weberian sense. There are some important features of Indonesian political culture within this framework:

- The existence of a culture of 'patron-client' relationships among state officials and many segments of society, particularly the business sector. This kind of relationship gave rise to strong 'patrimonialism' on almost all levels of society that, in turn, manifested itself, among other ways, in the culture of what is colloquially known a 'ABS' (Asal Bapak/Ibu Senang, or 'yes men').

- Unclear and inappropriate practices in government and bureaucracy. There seem to be no clear boundaries, for instance, between things that are official and those that are personal in nature.

- Weakness in social and public ethics.

- Weakness in law enforcement, as well as low ethics, credibility, accountability and morale of law enforcement agencies.

Furthermore, as far as Indonesia's 'Partnership for Governance Reform' is concerned, there is only very little understanding among state officials, as well as society at large, of the concept and practice of good governance. This is not surprising, since the executive branch of government has been the most dominant and unchallenged - and in many cases very arbitrary - institution at the expense of society in general - from the period of the 'Old Order' under President Soekarno and into the era of the 'New Order' (since the late 1960s under President Soeharto). The executive branch of the government was almost without control. Therefore, when the ideas of good governance gained momentum in post-Soeharto Indonesia, there had been no fertile ground to implant them.

The government is of course only one of the actors in governance. There are many other actors outside the executive branch of government, including the legislative and judicative branches which play an important role in the decisionmaking process. Even in a wider sense, other 'non-governmental' actors that also play a role in decision-making or in influencing the decision-making process, can be referred to as 'actors' of governance. They are, for instance, civil society organisations and groups, NGOs, research institutes, political parties, the military, religious leaders, public intellectuals, and others. Above all, however, ultimately 
it is again the government which is central in creating good governance. We shall discuss later the role of civil society in the eradication of corruption.

The creation of good governance, no doubt, needs an accurate understanding of the very concept and practice of governance. According to the concept of 'participatory governance', governance basically is good governance and good order of public life for a better shared life. Therefore, good governance is an order that makes it possible for the public to share a better life and at the same time is free from any kind of disorder and imbalance. Good governance includes eight major characteristics. It is

- participatory,

- consensus-oriented,

- accountable,

- transparent,

- responsive,

- effective and efficient,

- equitable and inclusive,

- and follows the rule of law.

With these characteristics, good governance assures that corruption, for instance, is minimised.

There is a great deal of very complex constraints in the creation of good governance; among others, are:

- lack of understanding of the concept and the necessity of good governance;

- lack of trust and cooperation between government bodies and agencies on the one hand and civil society on the other;

- absence of precedence and experience in Indonesia of the implementation and development of good governance.

Good governance, in many ways, is identical with governance that is free from KKN (korupsi, kolusi, nepotisme). The creation of good governance - in essence clean and capable government - can be achieved by reforming bureaucracy and public service. The aim of such reforms is to create transparency in bureaucratic processes and public service. To achieve this, it is necessary to improve the quality of human resources in the bureaucracy. Human resources development in bureaucracy should be more professional - from the recruitment of employees, through their conduct of public service, to their job promotion.

The reform of governance can also be referred to as 'reinventing of government'. Using the framework of Osborne and Gaebler,' 'reinventing government' has an orientation towards the creation of ten kinds of 'governance models': 
- catalyst government, which leads rather than dictates;

- society-owned government, which gives authority rather than being served;

- government with a mission, which transforms organisation of bureaucracy from simply works by regulations to missions;

- competitive government, which emphasises competitiveness in public service;

- result-oriented government, which has an orientation to results rather than simply the presence of employees;

- society-oriented government, which aims at fulfilling the needs of society rather than those of the bureaucracy;

- entrepreneurship government, which produces revenues rather than simply spends;

- anticipative government, which prevents rather than cures mistakes and failures;

- decentralised government;

- 'market-oriented'government, which encourages changes through market and public.

It is clear that the creation of good governance needs the participation of civil society and public as a whole. Indonesia's first Vice-President, Mohammad Hatta, once stated that corruption has been a 'part of culture' for many Indonesians. Bung Hatta, the other proclaimer of Indonesian independence besides Soekarno, is to a great degree right. Particularly now, corruption is so rampant, as if it is part and parcel of Indonesian culture. It appears that Indonesians in general - willingly or unwillingly - are now permissive of almost all kinds of corruption.

Therefore, by the same token, rampant practices of power arrogance and KKN in Indonesia have also been caused by public apathy. This originates from the public's unawareness of their rights as both citizens and subjects of public service and government bureaucracy. Often, the public does not even know how to file complaints or does not want to be bothered by complications resulting from their complaints of bad practices of bureaucracy. Therefore, dissemination of the ideas and practices of good governance is absolutely necessary: on what good governance is all about; on the benefits that the public can derive from good governance and, in reverse, on public disadvantages or even loss, resulting from bad governance.

\section{Civil Society and the War against Corruption}

A number of studies on civil society in Indonesia, such as those by Hefner ${ }^{10}$ and Nakamura, Siddique and Bajunid, ${ }^{11}$ have concluded that Muslim or Islamic-based civil societies and their leaders played a major and crucial role not only in the 'better ordering' of Indonesian Muslim society at large, but also in the eventual fall of 
President Soeharto's regime in 1998. Many leaders of Muslim or Islamic-based civil society organisations - the most prominent among them were Abdurrahman Wahid, also well-known as 'Gus Dur' (then the national leader of the Nahdlatul Ulama/ NU), Mohamad Amien Rais (then the national chief leader of Muhammadiyah), and Nurcholish Madjid (the former national leader of the Muslim University Students Association/HMI) - were among the most outspoken critics of the Soeharto regime and took the leading role in the increased prominence of civil society opposition to autocratic rule in Indonesia since the 1990s.

Indonesian religious-based civil society has a long and rich history. As has been shown by many scholars, the earliest form of nationwide civil society in the country were Muslim social-religious organisations such as Muhammadiyah (established in 1926), Nahdlatul Ulama or NU (founded in 1912), and many other national and local organisations. Muhammadiyah and NU were (and still are) the largest Muslim organisations in Indonesia, each of which now claims membership of some 35 million and 40 million, respectively. Voluntary, independent from the state, self-funded, self-sufficient, and self-regulating, the Muhammadiyah, NU, and many other Muslim organisations operate as mediating and bridging forces between state and society since their foundation up until today. From the colonial period up to now, these Islamic-based civil society organisations have been conducting a variety of programmes and activities, ranging from religious activities to social, cultural, educational, health, and economic ones.

The second kind of civil society organisations in Indonesia mostly appeared during the economic modernisation period of President Soeharto, roughly from the early 1970s to the second half of the 1990s. They are non-governmental organisations (NGOs), known in Indonesia initially as Lembaga Pengembangan Swadaya Masyarakat (LPSM, or organisations, or more precisely, 'Society Self-Development Groups') which in the current usage are popularly known as Lembaga Swadaya Masyarakat (LSM, or literally 'Institutions for Social Empowerment'). Most of these LSMs (NGOs) are non-religiously based, even though their activists by and large happen to be Muslims. However, an increasing number of Islamic-based NGOs have also made their appearance. These NGOs could also be regarded as advocacy NGOs working for the empowerment of society in such fields as democracy, human rights, gender equality, environmental preservation and others.

The third group of civil society organisations in Indonesia are professional associations, such as associations of teachers, medical doctors, and journalists, as well as labour movements and the like. Some of these associations are Islamicbased, like the All-Indonesian Association of Muslim Intellectuals (ICMI, or Ikatan Cendekiawan Muslim se-Indonesia), the United Muslim Labour Movement, etc. Even though these associations have increasingly become more vocal in furthering 
their own interests, they are rarely involved in much wider social, political and cultural issues.

The first two groups of civil society organisations have been directly or indirectly involved in many political, social, cultural and economic issues. That is why many leaders of civil society organisations during the last years of the Soeharto government tended to be heavily politicised. Moreover, soon enough they became politicians in the period following the downfall of President Soeharto, in May 1998, from his long-held grip of power of more than three decades. The question was whether or not they would be able to live up to the expectations of the public in general.

This can be clearly seen in the case of Abdurrahman Wahid, the national chairperson of the NU, who founded the Nation Awakening Party (Partai Kebangkitan Bangsal PKB), or Amien Rais, the national chief of Muhammadiyah, who established the National Mandate Party (Partai Amanat Nasional/PAN) in the period after President B.J. Habibie, who had replaced Soeharto and had introduced the liberalisation of Indonesian politics as well as a multiparty political system. Later, following the first democratic general elections of 1999, Rais was elected as the Speaker of the Indonesian People's Consultative Assembly (Majelis Permusyaratan Rakyat) MPR) - Indonesia's parliament - and Wahid was elected President of the Republic of Indonesia.

President Wahid, the former civil society leader, however, failed to meet public expectations. He was impeached by the MPR in 2001 following his controversial policies and statements as well as his erratic attitude and mismanagement. He was replaced by his vice-president, Megawati Soekarnoputri, the national chairperson of the Indonesian Democratic Party-Struggle (PDI-P) and one of the daughters of Soekarno, the first president of the Republic of Indonesia.

Despite the failure of Abdurrahman Wahid, many other civil society figures and public intellectuals continued to be tempted by power politics. The most striking example is Nurcholish Madjid, one of Indonesia's most prominent independent public intellectuals in contemporary times, who in the end could not resist political temptation: in 2003, he joined the presidential bid through the convention of the Golkar Party. However, he soon withdrew from power politics after he had understood the complexities of power politics within the Golkar Party. Other public intellectuals, such as Sjahrir and Ryaas Rasyid, founded their own party, which, nevertheless, fared poorly in the 2004 general elections.

This tendency continued during the 2004 general elections. A number of figures, known mainly as civil society leaders, such as Hasyim Muzadi, the national chairman of the NU, and Shalahuddin Wahid, Vice Chief of the Indonesian Human Rights Commission, joined the political battlefield. Muzadi became vice-presidential candidate of Megawati Soekarnoputri in her bid to win another term of presidency. In addition, Shalahuddin Wahid, the younger brother of Abdurrahman Wahid, was 
the vice-presidential candidate of the retired General Wiranto. They all failed in their bid. The winners of the direct presidential elections were Susilo Bambang Yudhoyono and Muhammad Jusuf Kalla, the current president and vice-president, respectively, of the Republic of Indonesia.

Therefore, as discussed by this writer elsewhere, ${ }^{12}$ the involvement of civil society figures and public intellectuals in Indonesian power politics during the so-called 'Reforms Period' (Masa Reformasi) has resulted not only in their failure, but also in the unmaking of civil society in Indonesia in general. The involvement and eventual failure of civil society leaders in Indonesian politics has resulted in a kind of frustration and disorientation of civil society organisations and groups. This is true not only in the case of religious-based civil society organisations like NU and Muhammadiyah, but also of advocacy NGOs, since many figures of the latter have also been pulled into politics. The implication has been far-reaching down to the grass-root level. There are cases where members of NU and Muhammadiyah were involved in mass-brawls during the period of President Abdurrahman Wahid. The fanatic NU supporters of President Wahid - on the edge of imminent impeachment - accused Muhammadiyah (to which the Speaker of the MPR happens to belong) and launched an anti-Wahid campaign.

The political situation, of course, has become more stable since the last years of President Megawati Soekarnoputri's term of office, and was even more conducive with the completion of the 2004 general elections. Since then, there are some good signs that civil society organisations and groups have been trying to reconsolidate themselves. Hasyim Muzadi, the chief leader of NU, for instance, has promised publicly that he would never again be involved in power politics. At the same time, Ahmad Syafii Maarif, the national chief of the Muhammadiyah continues to be firm that his organisation must hold fast to the idea of civil society. Muhammadiyah must continue not to be involved in practical, day-to-day and power politics.

With the continued stabilisation of Indonesian politics under the current President Yudhoyono and Vice-President Kalla, some crucial agendas have been put forward not only by the President, but also by Indonesian society in general. Among the foremost that have already been mentioned above are the creation of good governance, the eradication of rampant corruption, the continued recovery of the Indonesian economy, and the improvement of the enforcement of law and order. There is much hope that besides those government efforts civil society organisations and groups should play a greater role in all of these urgent agendas.

\section{Cultural and Political Constraints}

The noble ethical religious and cultural values and norms against the abuse of power and corruption have largely failed to eradicate this evil in Indonesia not 
only because of cultural and social disorientation among people, but also because of unfavourable political realities. Political liberalisation and the introduction of democracy following the fall of President Soeharto from power in 1998 have in fact resulted in an increase of the abuse of public positions. With the implementation programme of decentralisation and local autonomy, corruption and other kinds of KKN practices, for instance, have become even more rampant than ever before. The erosion of the power and authority of the central government, the lack or near absence of law enforcement, and the demoralisation of the law enforcement agencies are some of the contributing factors responsible for the more rapid spread of corruption in present-day Indonesia.

Even though Indonesia has a number of laws and regulations that could be used to combat corruption, the country has largely failed to address this issue. This has a lot to do also with the realities of Indonesian political culture and leadership. The current realities of both are not really conducive for anti-corruption efforts. Although Indonesia is now the third largest democracy - after India and the United States - its political culture is still dominated by a certain patrimonial culture, which is characterised by a patron-client relationship between the ruling elite and their subjects. This patrimonial political culture - as has been shown by such scholars as Max Weber, Benedict Anderson, Syed Hussein Alatas, and others - is also responsible for the spread of corruption and the use and abuse of public offices.

With the continued prevalence of this patrimonial political culture in Indonesia today, it is difficult to expect that anti-corruption laws and regulations can be enforced effectively. In fact, it is no secret that many, if not most, corruption cases are 'settled' behind closed doors. This, in turn, creates demoralisation and apathy among the people, who until now have been committed to the anti-corruption campaign.

Worse still, public leadership - particularly political leadership - from the national as well as local levels have mostly failed to show their political will and translate it into concrete action to combat corruption. In contrast, there is much reluctance among them to address the issue of corruption openly. If they do talk about it, it is largely for political consumption only, rather than for the sake of serious political will and action. The failure of public leadership in general to combat corruption has a lot to do also with their failure to present themselves as moral examples for the ordinary people. Many, if not most, of them are more interested in power rather in the creation of good governance which will restrict corruption and other kinds of the use and abuse of public offices for personal or collective gains.

At the public level, the anti-corruption campaign has been conducted mainly by relatively small NGOs with limited influence. Large social organisations - especially Muslim organisations such as the NU, Muhammadiyah and the like - which exert strong nationwide influence have only recently shown a special interest in the anti-corruption programme. In cooperation with the 'Partnership for Governance 
Reform' they have conducted anti-corruption campaigns and attempted to implement good governance within their own organisations. However, there is as yet much to be done before they can play a greater role in the creation of good governance. These organisations must further be empowered and also oriented not only towards anti-corruption programmes, but also towards the creation of good governance as a whole.

Education, no doubt, could play an important role in developing future leaders that have strong commitment to public ethics and morality. Therefore, the teaching of ethics, morality and noble religious values should be enhanced. The teachings of these values should not only be based on (and be for the sake of) memorisation, but more importantly for practical application in real life.

\section{Scaling-up the Momentum: Some Recommendations}

Again, with all the noble values and vibrant civil society, the Indonesian war against corruption should be scaled up.

- The country's KPK or 'Anti-Corruption Commission' should be strengthened, so that the efforts to combat corruption can reach a new level. The disclosure and trials of big corruption cases involving some high officials of Bank Mandiri, figures of the General Election Commission (KPU), former ministers, high-level officials of Bank Indonesia, including Aulia Pohan (father-in-law of President Yudhoyono's son), a good number of provincial governors, heads of districts, members of national and local parliaments, and many more give an even stronger hope of the eradication of corruption in the country. Despite these encouraging signs, there is still much more to be done in order to win the war against corruption which in the end will provide a more fertile ground for the creation of good governance.

As pointed out by the KPK, there are some important factors that make corruption remain rampant. The combination of a corruption-prone system combined with public office holders lacking integrity in addition to inconsistent law enforcement seems to make the problems worse. Not only that, law enforcement agencies and anti-corruption bodies responsible for investigating and bringing corruption cases to court have not been supported by sufficient funding. There is also strong evidence that many of the responsible and relevant institutions are still lacking the political will to fight corruption. Worse still, there is also widespread public permissiveness towards corruption. 
- Therefore, there should be a continued scaling-up of the momentum of the efforts towards combating corruption and creating good governance at all levels of society. Civil society organisations and groups in Indonesia - as suggested above - have been involved in the war against corruption and the creation of good governance. As also mentioned, since 2003 the two largest Muslim civil society organisations in the country, NU and Muhammadiyah, in cooperation with Indonesia's 'Partnership for Governance Reform' have launched a programme to combat corruption. In mid 2005, the Muhammadiyah chairperson Ahmad Syafii Maarif and his NU counterpart have signed an agreement to work together to fight corruption inside and outside their two organisations. ${ }^{13}$

It is clear that there is no resistance from within the two organisations in their fight against corruption. On the contrary, there is a lot of support. However, their joint efforts have yet to result in any progress, as some of their members are currently accused of involvement in corruption. Many leaders of NU and Muhammadiyah admit that the joint anti-graft movement remains ineffective, since there are no concrete programmes designed to follow up on it.

In July 2005, Indonesian President Susilo Bambang Yudhoyono, in his remarks at the opening ceremony of the Muhammadiyah national congress, ${ }^{14}$ said that this predominantly Muslim country should be very embarrassed by the fact that it was still considered one of the most corrupt nations in the world. President Susilo did not blame Islam for the widespread corruption, but said that "some Muslim individuals" were to be blamed for failing to embrace the Islamic teachings that, among others, prohibit Muslims to be involved in corruption.

In addition, in 2005 Jakarta's Syarif Hidayatullah State Islamic University began to prepare the introduction of a new course in its curriculum, called Pendidikan Anti Korupsi (Anti-Corruption Education), in cooperation with the United Nations Development Programme (UNDP) and 'Partnership for Governance Reform'. According to nationwide research conducted in preparation for the new course, many professors and lecturers believe that the anti-corruption course can give students a better perspective of many aspects of KKN - corruption, collusion, and nepotism - and the ways to combat them. The course will be introduced to all state universities and other interested universities across the country.

Thus, despite scepticism and pessimism among the Indonesian public, it is important to keep the flame of optimism alive. In concluding, one should thus not give in to pessimism about Indonesia. There are many creative, honest, hopeful people there and many positive things are occurring that are crucial both to win the war against corruption and to create good governance. 


\section{Notes}

1. Narrated by Ahmad, Bayhaqī, and Hakīm.

2. Mark Philip, "Defining Political Corruption", Political Studies 45, no. 3 (1997), 436-62.

3. Robert S. Leiken, 1996, "Controlling the Global Corruption Epidemic", Foreign Policy 105 (Winter 1996-97), 55-73.

4. World Bank, Helping Countries Combat Corruption: The Role of the World Bank (Washington DC: World Bank, 1997).

5. Syed Hussein Alatas, Corruption: Its Nature, Causes and Consequences (Aldershot [UK] and Brookfield VT: Avebury, 1990), 3-4.

6. Amanda L. Morgan, Corruption: Causes, Consequences, and Policy Implications: A Literature Review (San Francisco: The Asia Foundation, 1998), 6.

7. World Bank, Helping, 105.

8. Merle Calvin Ricklefs, "Susilo's War on Graft: Lots of Talk, Little Action", The Jakarta Post, 17 May 2005; see also The Jakarta Post, 30 May 2005.

9. David Osborne and Ted Gaebler, Reinventing Government: How the Entrepreneurial Spirit Is Transforming the Public Sector (Reading MA: Addison-Wesley, 1992).

10. Robert W. Hefner, Civil Islam: Muslims and Democratization in Indonesia (Princeton: Princeton University Press, 2000).

11. Mitsuo Nakamura, Sharon Siddique and Omar Faruk Bajunid (eds), Islam and Civil Society in Southeast Asia (Singapore: Institute of Southeast Asian Studies, 2001).

12. Azyumardi Azra, "Civil Society and Democratization in Indonesia: The Transition under President Wahid and Beyond", in: David G. Schak and Wayne Hudson (eds), Civil Society in Asia (Aldershot [UK]: Ashgate, 2003); Azyumardi Azra, "Civil Society and Democratization in Indonesia", in: Towards Good Society: Civil Society Actors, the State and the Business Class in Southeast Asia (Berlin: Heinrich Boehll Foundation, 2004); Azyumardi Azra, "Religious-Based Civil Society and Anti-Corruption Campaign: The Indonesian Experience in the Creation of Good Governance", in: Helen James (ed.), Civil Society, Religion and Global Governance: Paradigms of Power and Persuasion (Abingdon [UK]: Routledge, 2007).

13. The Jakarta Post, 7 July 2005.

14. Ibid. 